\title{
Review of Flow Hydrodynamics and Sediment Transport at Open Channel Confluences
}

\author{
Ananth Wuppukondur* \\ School of Civil Engineering, The University of Queensland, Australia
}

Submission: April 26, 2018; Published: June 14, 2018

*Corresponding author: Ananth Wuppukondur, School of Civil Engineering, The University of Queensland, Australia, Ph: +61 0431453 828; Email: a.wuppukondur@uq.edu.au

\begin{abstract}
Confluences are common occurrences along the natural rivers as well as artificial open channels. A confluence is characterized by the presence of a stagnation zone, a separation zone, a mixing layer and the recovered flow in the downstream. The bed erosion occurs because of turbulence at the confluence. The eroded soil at the confluence poses problems by deposition in the downstream locations such as check dams, barrages, and reservoirs if not controlled, resulting in reduction of water storage capacity as well as water quality. Recently, the number of studies on the confluences have increased, however, link between flow hydrodynamics and sediment transport, bed morphology at the confluence is still incompletely understood. In this paper, earlier studies on open channel confluences are discussed to summarize flow hydrodynamics and sediment transport phenomenon.
\end{abstract}

Keywords: River confluence; Hydrodynamics; Shear layer; Bed erosion; Sediment transport

\section{Introduction}

A confluence is a place where two flows with different flow and sediment characteristics merge together. Confluences are common occurrences along the natural rivers as well as artificial open channels. In general, a lateral flow confluences into a main flow at various angles. The confluence angle influences the flow and sediment transport at the confluence region. The bed erosion occurs because of turbulence at the confluence. Sometimes, the bank opposite to the direction of lateral flow fails due to the increase in lateral momentum. In addition, the main flow width in the downstream of the confluence increases due to increase of discharge. A confluence is characterized by the presence of a stagnation zone, a separation zone, a mixing layer and the recovered flow in the downstream. A secondary circulation (helicoidal flow cells) induced by the centrifugal action of the lateral flow when merging with the main flow leads to formation of a scour-hole along the central portion of the confluence. The eroded soil from the confluence poses problems by deposition in the downstream locations such as check dams, barrages and reservoirs resulting in reduction of water storage capacity as well as water quality. Hence, this necessitates studies on control of bed erosion at the confluence.

In this paper, earlier studies on open channel confluences are discussed to summarize flow hydrodynamics and sediment transport phenomenon. The efforts to understand the fluvial processes at confluence were made in different disciplines including hydraulics [1-4], sedimentology [5-7], ecology [8,9]. The early studies on open channel confluences were conducted on rigid bed models to understand various flow characteristics such as flow depths, separation zone, and velocity patterns. The studies on river confluences were carried out in laboratory experiments by Taylor [10], Ramamurthy et al. [1], Best and Roy [11], Escauriaza et al. [12], and field studies at river confluence are conducted by Best [6], Rhoads [13], Biron et al. [14], Lane et al. [15], etc. Later, studies were conducted to study sediment transport and scour phenomenon at river confluence on mobile bed models. The hydrodynamics and sediment transport at river confluences are explained in the present paper.

\section{Flow Hydrodynamics at Confluences}

\section{Flow depths and separation zone}

An open channel confluence is characterized by presence of a stagnation zone, detached flow at the downstream corner called separation zone, flow constriction opposite to separation zone and fully recovered flow beyond separation zone (Figure 1). The prediction of afflux on the upstream of confluence helps in determining the flood level and also for provision of freeboard in case of artificial canals. This section discusses variation of flow depth in the main, lateral and downstream channels at the confluence due to merging of flows and the factors affecting the flow depth at the upstream of the confluence. 


\section{Civil Engineering Research Journal}

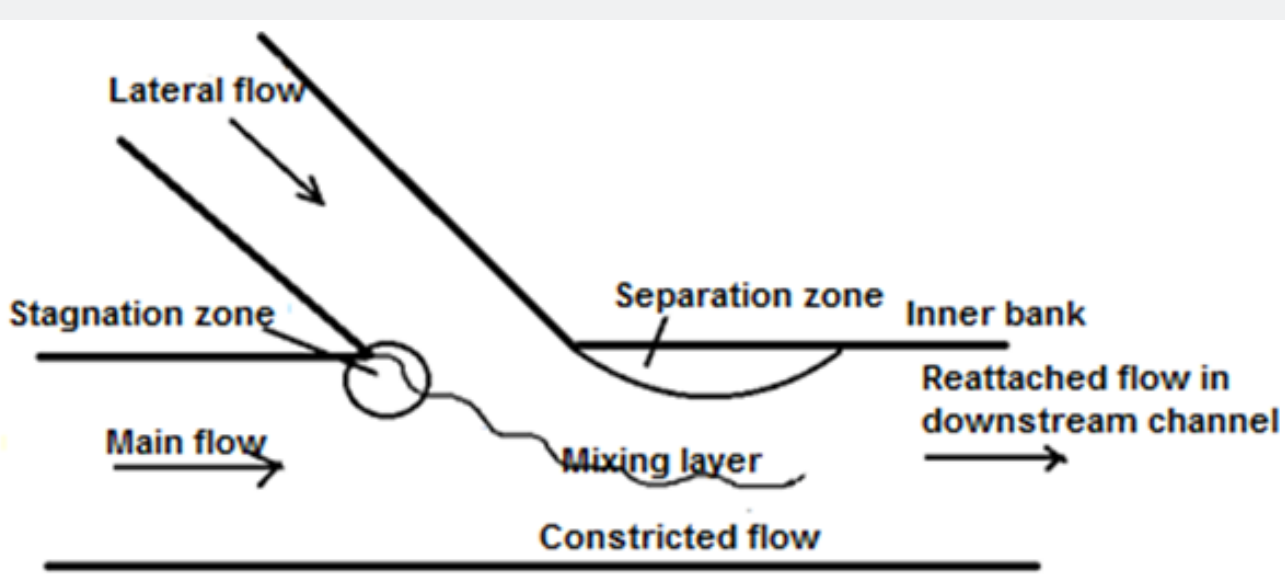

Outer bank

Figure 1: Different flow zones identified at a open-channel confluence.

The lateral flow transfers momentum while merging with the main flow at the confluence. The momentum from lateral flow depends on discharge and flow velocity of the lateral flow. The deceleration of flow at the upstream sections of confluence due to the momentum transfer leads to conversion of velocity head to hydraulic head which causes rise in flow depth in the upstream [1,10,16-19]. The depth ratio (ratio of main and downstream flow depths) depends on discharge ratio ( =ratio of discharge in lateral flow to that of main flow) and also on the junction angle $[17,20]$. Reverse flow along the lateral channel was also observed due to partial diversion of flow from main channel to the lateral channel in case of low discharge ratios [21]. The depth ratio is more in subcritical flow than transitional flow because of low velocity and high flow depth associated with subcritical flow [22]. As the discharge ratio increases, the momentum of lateral flow increases and pushes the main flow towards outer bank and acts as an obstruction to the incoming flow in the main channel. This causes rise in flow depth at outer bank in the downstream channel.

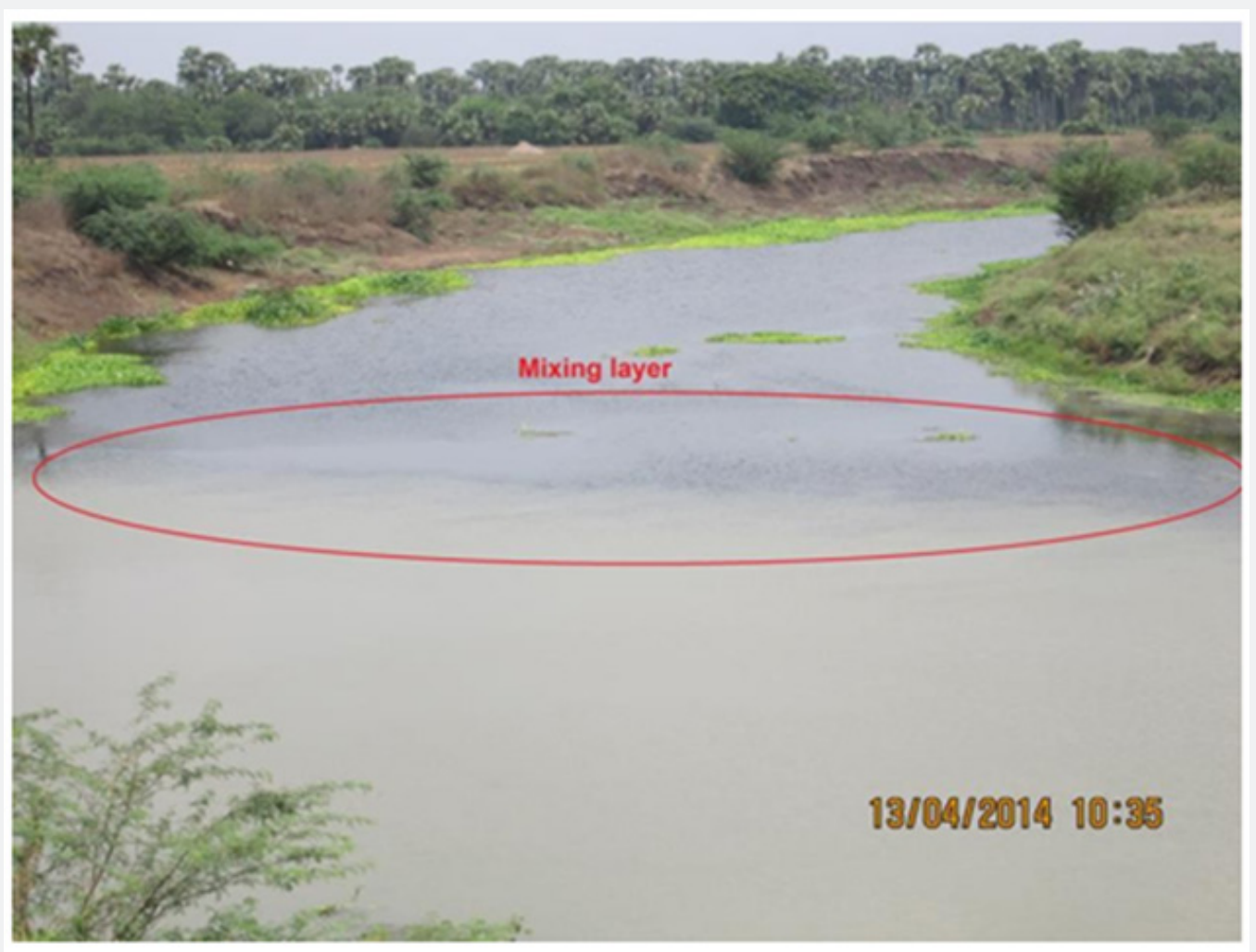

Figure 2: Mixing layer along the confluence (source: from field visit). 


\section{Civil Engineering Research Journal}

Separation zone is a common characteristic observed at river confluences. When the lateral flow merges with the main flow at the confluence, the momentum transfer occurs from lateral to the main flow and hence the flow in the main channel is pushed towards outer bank. This creates a recirculation zone with low velocities called Separation zone near the inner bank of the confluence. This separation zone extends up to certain distance downstream of the confluence leading to constriction of flow in the downstream channel at the separation zone and the flow then recovers to full width of channel. At the separation zone, the flow depth decreases as the flow gets deflected from the inner bank which leads to flow concentration towards the outer bank $[6,23]$. The water level at the separation zone decreases upto 15\% less than that of main flow depth and the difference in water levels at inner bank and outer bank at the separation zone is upto 5\% [24]. The minimum depth of flow in the separation zone occurs for the minimum discharge ratio [25]. The separation zone is characterized by presence of a sediment bar along the inner bank of the confluence [26-30]. Sorting of sediments and also deposition occurs at the separation zone which leads to form discordant beds [31] (Figure 2).

As the momentum transfer increases with increase of discharge ratio, the shape index of separation zone, $\alpha$ (ratio of width to length of separation zone) increases $[5,17,23]$. The separation zone index is affected by the junction angle $[17,25]$. Since the momentum transfer occurs in more or less same direction as that of the main flow, at small junction angles, the discharge ratio does not affect the separation zone [25]. Hence, the flow constriction increases with an increase of junction angle at the separation zone. The coefficient of contraction which is the ratio of width of flow at separation zone and the downstream channel width, increases with increasing junction angle. The discharge ratio has less impact on size of separation zone in transitional flows because of formation of hydraulic jump at the confluence [25]. The size of separation zone in subcritical flow is higher than that of transitional flow [22]. Separation zone is may not be observed in case of confluences with discordant beds because of turbulence created by bed difference [32].

\section{Velocity distribution and mixing}

Flow velocities at the confluence vary from ambient flows due to merging of two different flows. The near bed velocities at the separation zone are similar to that of ambient flow. Whereas, at the separation zone, surface flow has less velocities compared to velocities at the bed level and also has recirculating velocities. The near bed velocities at the confluence increase with discharge ratio which causes soil erosion and sediment transport [5]. Also, the flow constriction at the separation zone has direct impact on the flow velocities which increase away from the separation zone $[18,25]$. Hence, the velocities along the inner bank are lesser than the outer bank [33-35]. In addition, modification of downstream channel geometry also affects the flow conditions at the confluence [36].
The interaction of the two merging flows depends on the lateral flow momentum [15,34,37-39]. The lateral advection of momentum results in acceleration of fluid in the central portion of the combining flows and the two velocities will be gradually merged in to a single velocity along the mixing layer $[15,37,40,41]$. Mixing layer with distinct flow and sediment characteristics of merging flows along a natural confluence is shown in Figure 2. The shear layer or mixing layer extends upto three to four times the channel width in the downstream of the confluence which occupies a partial portion of the flow crosssectional area at the confluence. The shear layer moves from one side of the confluence to the other with change in discharge ratio $[37,42,39]$. High flow turbulence intensity and high shear stresses are observed within the shear layer with Turbulence Kinetic Energy (TKE) within this layer being two to three times higher than usual flow [43]. In addition, coherent rotating vortices form within the shear layer $[44,41]$.

A hydraulic jump was forms at the confluence under certain flow conditions. The formation and position of hydraulic jump at the confluence depends on the geometry of the channels as well as the inflow Froude numbers [45]. However, a hydraulic jump may not form at the junction all the times [46]. The hydraulic jump forms in the downstream channel only when the discharge ratio exceeds $0.127[47,48]$. This indicates a lower bound for lateral flow discharge to form a jump. For a given main flow Froude number, the jump forms only for higher discharge ratios at smaller confluence angles. Beyond discharge ratio of 0.37 , hydraulic jump does not form at the confluence. The discharge ratio, Froude number, width ratio and confluence angle control the formation of hydraulic jump at the confluence [48].

\section{Sediment Transport}

Erosion and deposition are the processes of removal and transport of sediment till settle down at low velocity regions. The flow velocity at which sediment particles start moving is called entrainment velocity. Each size of grains has a particular entrainment velocity. Hence, the flow should attain the entrainment velocity in order to erode the soil. The bed erosion occurs if the movement of water exerts the shear stress more than critical shear stress required for the movement of particles. The eroded particles at a location may lead to deposition at some other location in the downstream due to decrease in velocity. This cyclic process of erosion and deposition occurs throughout the length of the river. The amount and size of sediment moving in a river are determined by three factors viz., entrainment velocity, flow capacity and sediment supply. The other sources for bed erosion are flow in culverts and around bridge piers. The enormous amount of sediment being carried in the flow causes decreasing storage capacity of a reservoir.

The convergence of flows at a confluence often leads to erosion of the riverbed and formation of a deep scour at the confluence [49]. A secondary circulation (helicoidal flow cells) induced by the centrifugal action of the lateral flow when 


\section{Civil Engineering Research Journal}

merging with the main flow leads to formation of a scour- hole along the central portion of the confluence $[26,29,44,40,49,50]$. Increased velocities and turbulence along the central region of the confluence cause bed erosion. Best and Ashworth reported a scour-hole as large as $400 \mathrm{~m} \times 2000 \mathrm{~m}$ at the GangesBrahmaputra River confluence in Bangladesh, which migrated $3.5 \mathrm{~km}$ downstream in only 28 months. The scour at the confluence affects the downstream flow velocity which results in formation of vortices due to change in hydraulic conditions $[11,44,51]$. The maximum scour depth at the confluence could be four to five times the average flow depth of the incoming flows [52-54]. The confluence scour changes from elliptical to more circular with an increase of confluence angle and it also depends on the symmetry of the confluence angle [49]. Thus, with an increase of confluence angle, the scour depth increases because of increase in momentum [28,55]. In addition, the scour depth increases with an increase of discharge ratio [28,34,29]. The scour depth at the confluence is maximum when the confluence is symmetrical and both main and lateral discharges are equal. The scour-hole is observed along the central portion of the confluence, bisecting the confluence angle, if the discharge in both the incoming flows is equal, otherwise, the scour-hole tends to be parallel to the dominant flow direction [49]. The position of the scour-hole depends on the flow momentum ratio between the two confluent rivers [15,28,38,49,52]. Further, the size and location of scour-hole are studied in natural confluences by Rhoads and Sukhodolov [37], Riley and Rhoads [56], Riley et al. [57], and experimental studies are conducted by Best [58], Boyer et al. [42], etc.

In alluvial rivers, channel morphology and sediment transport processes are inevitably linked [59]. It is observed that generally, the difference between the flow and sediment characteristics of two merging flows such as discharge, flow depth and sediment concentration impact the mixing process at the confluence. Mixing of flows at the water surface level along the confluence depends on the hydrological seasons and the yearly hydrological regime. The highest mixing of flows occurs during peak discharge seasons and lowest during rising discharge seasons [60]. Edward et al. estimated the complete mixing time and distance at Solimos and Negro confluence were around 30 hours and $100 \mathrm{~km}$, respectively. Highest mixture of sediments occurs at the bed level because of change in velocities and hence, high-density flows are observed near bed zones $[61,62]$. The sediment distributions across the main and lateral flows influence the distribution of suspended sediment at the confluence. The increased turbulence levels at the confluence lead to an increase of the sediment transport capacity along shear layer of the confluence [29]. The stagnation point at the upstream corner causes an asymmetric distribution of the flow and sediment transport. Hence, the greatest sediment transport occurs around the edges of the scour-hole which is generally observed at the downstream corner of the confluence [63]. The lateral flow characteristics play a key role in controlling the grain size and sorting of bed material in the downstream direction of the confluence $[13,64-69]$.

\section{Discussion of Previous Literature}

The discussion of previous literature is presented in two sections,

(i) Experimental studies and

(ii) Numerical studies.

\section{Experimental studies}

Taylor [10] was the first to report the study on open channel junction flows. This study was analytical work based on momentum principle applied to simple open channel junction geometry. By assuming simple channel geometry and boundary conditions, he derived a non-dimensional expression for rise in upstream flow depth for $45^{\circ}$ junction angle. He also provided a graphical solution for rise in upstream flow depth. His study was restricted only to subcritical flows. The analytical work of Taylor [10] was extended by Webber \& Greated [70] experimentally in predicting the flow depth rise at the junction with momentum principle. They defined a theoretical flow pattern at the junction region using a conformal mapping method. Experiments were conducted with junction angles of $30^{\circ}, 60^{\circ}$ and $90^{\circ}$ with subcritical flows. The observations were agreeable with that of Taylor [10] at small junction angles and discharge ratios but differ at higher junction angles and discharge ratios.

Later, a non-dimensional relationship for rise in flow depth was developed by Ramamurthy et al. [1] using discharge ratio and main flow Froude number for subcritical flows. This relation was obtained based on the experimental results on right angled rectangular channel junctions of equal width with varying discharge ratios. A 1D approach was presented by Hsu et al. [17] for determining the upstream depth of right angled junction of rectangular channels with transitional flows. Afflux because of merging flow was observed using water surface mapping by Weber et al. (2001). The separation zone was identified using different experiments by Bryan and Kuhn [27], Liu et al. [34], Birjukova et al. [35], etc.

The velocity pattern at the confluence was studied by Joy and Townsend [36], Weber et al. [24], etc. Experiments were conducted by Weber et al. [24] to obtain velocity patterns and shear stress distribution. They presented 3D flow velocities for right angled rectangular channel junction for varying discharge ratios. The separation zone was also identified using the velocity mappings. The scour phenomenon at river confluences was studied experimentally by Mosley [44], Ghobadian \& Bajestan [71], Bejestan \&Hemmati [72] , Borghei \& Sahebari [28], Ribeiro et al. [29,43] , Giglou et al. [55], etc. The studies were conducted on mobile bed confluence models with rigid side walls and discussed about the maximum scour depth and scour-hole. The above mentioned studies investigated the influence of discharge ratio, flow widths, particle grain size and confluence angle 
experimentally. Many studies including Webber and Greated [70], Best [6], Hager [25], Ramamurthy et al. [1], Gurram et al. [20], Hsu et al. [17], Shakibainia et al. [73], Mignot et al. [39,74], Schindfessel et al. [23] have identified discharge ratio as an important parameter influencing flow and sediment transport at the confluence. Vanes and circular piles have been shown to reduce the flow velocities and secondary circulation along the mixing layer and as a result reduced bed erosion was reported by Wuppukondur and Chandra $[75,76]$.

\section{Numerical studies}

Bradbrook et al. $[77,78]$ used $\kappa-\varepsilon$ model to study flow features such as the separation zone and secondary circulation at confluence. They reported that momentum ratio is a key parameter in controlling separation zone. In this steady flow model, secondary circulation increases due to bed discordance at the confluence. Large Eddy Simulation (LES) was used by Bradbrook et al. [79] to study unsteady flow conditions at the confluence. Huang et al. used $\kappa-\omega$ model to simulate flow in a right angled open channel junction and the simulation results were in good agreement with experimental results. Frizzell et al. [80] used a 2D depth averaged, $\kappa-\varepsilon$ model to study the flow phenomenon at confluence. The model over predicted the length of separation zone compared to experiments but was accurate in predicting the width of separation zone. The results of a 1D model developed by Ghostine et al. [81] were compared with 2D model solving Saint Venant equations. They reported that 1D model performed well only for small confluence angles and discharge ratios. Whereas, for higher confluence angles and discharge ratios, performance of 2D model was compared with experimental results and found that 2D model predictions were better when compared with 1D model. A 3D numerical model was used by Yang and Chen [82] to study separation zone and secondary circulation at confluence. They assumed fully turbulent flow in the 3D model, but the flow is transition from laminar to turbulent in the experimental study. They found that the simulated results were under predicting compared with experimental results due to this flow transition.

The mixing process at confluence with concordant and discordant beds was studied using a 3D model and field measurements by Biron et al. [32]. The 3D model simulation results showed that the influence of discordant bed on the mixing process at the confluence was found to be less compared to field measurements. However, a wide range of confluence angles and discharge ratios were considered in an experimental study by Shaekibaenia et al. and used a 3D numerical model to compare the flow phenomenon at the confluence.

A multilayer functional link neural network (MFLN) method was used by Yang \&Chen [82] to investigate flow velocities at the confluence and observed good match between simulated and measured results. Two ANNs namely Multi-layer Perception (MLP) and Radial basis function (RBF) were used by Balouchi et al. to predict maximum scour depth and compared with experimental results. The MLP model predicted accurate results for low discharge ratios and RBF predicted better results for high discharge ratios. Further, the flow characteristics at river confluence was studied numerically by Shakibainia et al. [73,83], Shi-he and Bing [84], Baranya et al. [85], and Lyubimova et al. [61]. It shows that the earlier numerical studies on confluence have emphasized more on studying the flow phenomenon with only a few studies on sediment transport.

\section{Conclusion}

Recently, the number of studies on the confluences have increased, however, link between flow hydrodynamics and sediment transport, bed morphology at the confluence is still incompletely understood. Most of the previous studies were performed to understand the hydrodynamics at the confluence using rigid bed models $[2,16,32,35,40,48]$. These studies provided clear implications of bed erosion and sediment transport. A few studies on sediment transport highlighting scour phenomenon and deposition processes at river confluence were performed using mobile bed physical models in the laboratory $[28,44,55,58]$. The eroded soil at the confluence poses problems by deposition in the downstream locations such as check dams, barrages, and reservoirs if not controlled, resulting in reduction of water storage capacity as well as water quality. Kothyari [86] reported that by 2020, 30 major reservoirs and by 2050, 80\% of the existing reservoirs in India will lose half of their original capacity. It is reported that reservoirs all over the world are losing storage capacity by as much as $5 \%$ every year. In addition, the flow at the confluence concentrates more towards the outer bank causing bank erosion due to flow separation. This results in river bank failure and inundation in the adjacent areas along the river bank. Hence, this necessitates studies on control of bed erosion and controlling the flow movement towards outer bank at the confluence.

\section{Acknowledgement}

The author would like to thank Dr. Venu Chandra, Assistant Professor, Department of Civil Engineering, Indian Institute of Technology Madras, India for help in preparing the manuscript.

\section{References}

1. Ramamurthy A, Carballada L, Tran D (1988) Combining open channel flowatrightangled junctions. Journal of Hydraulic Engineering 114(12): 1449-1460.

2. Hager WH (1995) Experiments to supercritical junction flow. Experiments in Fluids, pp. 429-437.

3. Constantinescu G, Miyawaki S, Rhoads B, Sukhodolov A, Kirkil G (2011) Structure of turbulent flow at a river confluence with momentum and velocity ratios close to 1: Insight provided by an eddy-resolving numerical simulation. Water Resources Research 47(5).

4. Constantinescu G,MiyawakiS, Rhoads S, SukhodolovA(2012) Numerical analysis of the effect of momentum ratio on the dynamics and sediment entrainment capacity of coherent flow structures at a stream confluence. Journal of Geophysical Research 117: 1-21. 


\section{Civil Engineering Research Journal}

5. Best J, Reid I (1984) Separation zone at open channel junctions. Journal of Hydraulic Engineering 110(11):1588-1594.

6. Best JL (1985) Flow dynamics and sediment transport at river channel confluence. PhD dissertation, Birbeck College, University of London, UK, pp.393.

7. Rice S, Church M (2001) Longitudinalprofiles in simple alluvial systems. WaterResources Research 37(2): 417-426.

8. Benda L, Andras K, Miller D, Bigelow P (2004) Confluence effects in rivers: Interactions of basin scale, network geometry, and disturbance regimes. Water Resources Research 40(5).

9. Blettler M, Amsler M, Ezcurra de Drago I, Espinola L, Eberle E, et al. (2014) The impact of significant input of fine sediment on benthic fauna at tributary junctions: a case study of the Bermejo-Paraguay River confluence, Argentina. Ecohydrology 8(2): 340-352.

10. Taylor EH (1944) Flow characteristics at rectangular open-channel junctions. Transactions, Journal of Hydraulic Engineering 109(1): 893902.

11. Best J, Roy A (1991) Mixing-layer distortion at the confluence of channels of different depth. Nature 350(6317): 411-413.

12. Escauriaza C, Gonzalez C, Guerra P, Pasten P, Pizarro G (2012) Formation and fate of contaminant particles controlled by turbulent coherent structures and geochemistry in a reactive river confluence. Bulletin of the American Physics Society 57.

13. Rhoads BL (1987) Changes in stream channel characteristics at tributary junctions. Physical Geography 8(4): 346-361.

14. Biron PM, Richer A, Kirkbride AD, Roy AG, Han S (2002) Spatial patterns of water surfacetopographyatariverconfluence.EarthSurfaceProcesses andLandforms27(9): 913-928.

15. Lane SN, Parsons DR, Best JL, Orfeo O, Kostaschuk RA, et al. (2008) Causes of rapid mixing at a junction of two large rivers: Río Paraná and Río Paraguay, Argentina. Journal of Geophysical Research 113(F02019)

16. Greated CA (1968) Supercritical flowthroughajunction. Houilleblanche 23(8): 693-696.

17. Hsu C, Wu F, Lee W (1998) Flow at $90^{\circ}$ equal-width open-channel junction. Journal of Hydraulic Engineering 124(2):186-191.

18. Wang Xiekang, Wang Xianye LU, Weizhen Liu, Tonghuan (2007) Experimental study on flow behavior at open channel confluences. Frontiers of Architecture and Civil Engineering, China 1(2): 211-216.

19. Pinto Coelho M (2015) Experimental determination of free surface levels at open-channel junctions. Journal of Hydraulic Research 53(3): 394-399.

20. Gurram S, Karki K, Hager W (1997) Subcritical Junction Flow. Journal of Hydraulic Engineering 123(5): 447-455.

21. Alam M, Crook K, Taylor G (1985) Fluvial herring-bone crossstratification in a modern tributary mouth bar, Coonamble, New South Wales, Australia. Sedimentology 32(2):235-244.

22. Biswal SK (2012) An experimental study of flow at a right angled compound open channel junction. PhD Thesis, Indian Institute of Technology Kanpur, India.

23. Schindfessel L, Creëlle S, De Mulder T (2015) Flow patterns in an open channelconfluence with increasingly dominant tributary inflow. Water $7(9): 4724-4751$.

24. Weber L, Schumate E, Mawer N (2001) Experiments on flow at a $90^{\circ}$ open-channel junction. Journal of Hydraulic Engineering 127(5): 340350
25. Hager WH (1989) Transitional flow in channel junctions. Journal of Hydraulic Engineering 115: 243-259.

26. Rhoads BL, Kenworthy ST (1995) Flow structure at an asymmetrical stream confluence. Geomorphology 11(4): 273-293.

27. Bryan R, Kuhn N (2002) Hydraulic conditions in experimental rill confluences and scour in erodible soils. Water Resources Research 38(5): 21-1-21-13.

28. Borghei S, Sahebari A (2010) Local scour at open-channel junctions. Journal of Hydraulic Research 48(4): 538-542.

29. Ribeiro LM, Blanckaert K, Roy A,Schleiss A(2012a) Flowand sediment dynamics in channel confluences. Journal of Geophysical Research: Earth Surface 117(f1): 1-19.

30. Guillén-LudeñaS, FrancaM,Cardoso A,Schleiss A(2016)Hydro-dynamic evolutionina $90^{\circ}$ movable bed discordant confluence with low discharge ratio. Geomorphology 255: 1-15.

31. Riberio (2011) Influence of Tributary Widening on Confluence Morphodynamics. PhD Thesis, EPFL.

32. Biron P, Best JL, Roy AG (1996) Effects of bed discordance on flow dynamicsat open channel confluences. Journal of Hydraulic Engineering 122(12): 676-682.

33. Biswal S, Mohapatra P, Muralidhar K (2010) Flow separation at an open channel confluence. ISH Journal of Hydraulic Engineering 16(sup1): 89-98.

34. Liu T, Chen L, Fan B (2012) Experimental study on flow pattern and sediment transportation at a $90^{\circ}$ open-channel confluence. International Journal of SedimentResearch 27(2): 178-187.

35. Birjukova 0, Guillen S, Algeria F, Cardoso AH (2014) Three dimensional flow field at confluent fixed-bed open channels. Proceedings of River Flow 1007-1014.

36. Joy DM, Townsend RD (1981) Improved flow characteristics at a $90^{\circ}$ channel confluence. Proceedings of 5th Canadian Hydrotechnical Conference, Fredericton, NB, Canada, pp. 781-792.

37. Rhoads BL, Sukhodolov AN (2001) Field investigation of threedimensional flow structure at stream confluences: 1 . Thermal mixing and time-averaged velocities. Water Resources Research 37(9): 2393-2410.

38. ParsonsD, BestJ, LaneS, OrfeoO,HardyR,et al.(2006) Form roughnessthe absence of secondary flow in a large confluence-diffluence, Rio Paraná, Argentina.Earth Surface Processes and Landforms 32(1):155-162.

39. Mignot E, Vinkovic I, Doppler D, Riviere N (2013) “Mixing layer in openchannel junction flows". Environmental Fluid Mechanics 14(5): 10271041.

40. Roy A, Bergeron N (1990) Flow and particle paths at a natural river confluence with coarse bed material. Geomorphology 3(2):99-112.

41. Rhoads B, Sukhodolov A (2004) Spatial and temporal structure of shear layer turbulence at a stream confluence. Water Resources Research $40(6)$.

42. Boyer C, Roy A, BestJ (2006) Dynamics of a river channel confluence with discordant beds: Flow turbulence, bed load sediment transport, and bed morphology. Journal of Geophysical Research 111(F4).

43. Ribeiro LM, Blanckaert K, Roy AG, Schleiss AJ (2012b) Hydromorphological implications of local tributary widening for river rehabilitation. Water Resources Research 48(10): 1-19.

44. Mosley MP (1976) An Experimental Study of Channel Confluences. Journal of Geology 84(5): 535-562.

45. Bowers CE (1950) Hydraulic model studies for Whiting Field Naval Air Station, Part V: Studies of open-channel junctions. Technical Papers, 


\section{Civil Engineering Research Journal}

Series B, St Anthony Falls Laboratory, Univ. of Minnesota, Minneapolis, Minn.

46. Mignot E, Rivière N, Paquier A, Perkins R (2011) Hydraulic Models of the Flow Distribution in a Four Branch Open Channel Junction with Supercritical Flow. Journal of Hydraulic Engineering 137(3): 289-299.

47. Rice CE (1985) Open channel junctions with supercritical flow. National Technical Information Service.

48. Christodoulou G (1993) Incipient Hydraulic Jump at Channel Junctions. Journal of Hydraulic Engineering 119(3): 409-423.

49. Ullah MS, Bhattacharya JP, Dupre WR (2015) Confluence scours versus incised valleys: Examples from the Cretaceous Ferron-Notom Delta, Southeastern Utah, USA. Journal of Sedimentary Research 85(5): 445458.

50. Rhoads BL, Parsons DR, Johnson KK (2015) Influence of junction angle on three dimensional flow structure and bed morphology at confluent meander bends during different hydrological conditions. Earth Surface Processes and Landforms 40(2): 252-271.

51. Best J, Ashworth P (1997) Scour in large braided rivers and the recognition of sequence stratigraphic boundaries. Nature 387(6630): 275-277.

52. Ashmore PE, Parker G (1983) Confluence scour in coarse braided streams. Water Resources Research 19(2):392-402.

53. Bridge JS, Demicco RV (2008) Earth Surface Processes, Landforms and Sediment Deposits. Cambridge, UK, Cambridge University Press, pp. 392

54. Eilertsen R, Hansen L (2008) Morphology of river bed scours on a delta plain revealed by interferometric sonar. Geomorphology 94(1-2): 5868.

55. Nazari-Giglou A, Jabbari-Sahebari A, Shakibaeinia A, Borghei S (2016) An experimental study of sediment transport in channel confluences. International Journal of Sediment Research 31(1): 87-96.

56. Riley J, Rhoads B (2012) Flow structure and channel morphology at a natural confluent meander bend. Geomorphology 163-164:84-98.

57. Riley J, Rhoads B, Parsons D, Johnson K (2014) Influence of junction angle on three- dimensional flow structure and bed morphology at confluent meander bends during different hydrological conditions. Earth Surface Processes and Landforms 40(2):252-271.

58. Best JL (1988) Sediment transport and bed morphology at river channel confluences. Sedimentology 35(3): 481-498.

59. Church M (2006) Bed material transport and the morphology of alluvial river channels. Annual Review of Earth and Planetary Science 34: 325354.

60. Park E, Latrubesse E (2015) Surface water types and sediment distribution patterns at the confluence of Mega Rivers: The SolimõesAmazon and Negro Rivers junction. Water Resources Research 51(8): 6197-6213.

61. Lyubimova T, Lepikhin A, Konovalov V, Parshakova Y, Tiunov A (2014) Formation ofthe density currents in the zone of confluence of two rivers Journal of Hydrology 508:328-342.

62. Martin-Vide JP, Plana-Casado A, Sambola A, Capape S (2015) Bedload transport in a river confluence. Geomorphology 250:15-28

63. Szupiany R, Amsler M, Parsons D, Best J (2009) Morphology, flow structure, and suspended bed sediment transport at two large braid-bar confluences.WaterResources Research 45(5).

64. Miller JP (1958) High mountain streams effects of geology on channel characteristics and bed material. New Mexico Bureau Mines and Mineral Resources Memoir 4: pp.53.
65. Lodina RV, Chalov RS (1971) Effect of tributaries on the composition of river sediments and of deformation of the main river channel. Soviet Hydrology, Selected papers 4:370-374.

66. Livesey RH (1976) The sedimentary influence of a tributary stream growth on the Niobara delta. Proceedings of Third Federal Inter-agency Sedimentation Conference 4:126-137.

67. Knighton AD (1980) Longitudinal changes in size and sorting of stream-bed material in four English rivers. Geological Society of American Bulletin 91(1): 55-62.

68. Troutman BM (1980) A Stochastic model for particle sorting and related phenomena. Water Resources Research 16:65-76.

69. William WD, Geoffrey CP, Judith LM (2009) Large channel confluences influence geomorphic heterogeneity of a southeastern United States river. Water Resources Research, Vol 45.

70. Webber N, Greated C (1966) An investigation of flow behaviour at the junction of rectangular channels. Proceedings of the Institution of Civil Engineers 34(3): 321-334

71. Ghobadian R, Bejestan MS (2007) Investigation of sediment patterns at river confluence. Journal of Applied Science 7(10): 1372-1380.

72. Bejestan MS, Hemmati M (2008) Scour depth at river confluence of unequal bed level. Journal of Applied Science 8(9): 1766-1770.

73. Shakibainia A, Reza M, Tabatabai M, Reza Zarrati A (2010) Threedimensional numerical study of flow structure in channel confluences. Canadian Journal of Civil Engineering 37(5): 772-781.

74. Mignot E, Bonakdari H, Knothe P, Lipeme Kouyi G, Bessette A, et al (2012) Experiments and 3D simulations of flow structures in junctions and their influence on location of flowmeters. Water Sci Technol 66(6): $1325-1332$.

75. Wuppukondur A, Chandra V (2017a) Methods to control bed erosion at 900 river confluence: An experimental study. International Journal of River Basin Management, Taylor \& Francis Publications.

76. Wuppukondur A, Chandra V (2017b) Control of bed erosion at 600 river confluence: An experimental study. International Journal of Civil Engineering, Springer publications.

77. Bradbrook KF, Biron PM, Lane SN, Richards KS, Roy AG (1998) Investigation of controls on secondary circulation in a simple confluence geometry using a three-dimensional numerical model. Hydrologic Processes 12(8):1371-1396.

78. Bradbrook KF, Lane SN, Richards KS, Biron PM, Roy AG (2000a) Large eddy simulation of periodic flow characteristics at river channel confluences. Journal of Hydraulic Research 38(3): 207-215.

79. Bradbrook KF, Lane SN, Richards KS (2000b) Numerical simulation of three-dimensional, time-averaged flow structure at river channel confluences. Water Resources Research 36(9): 2731-2746.

80. Frizzell C, Khan A, Werth D (2008) Numerical Simulation of Equal and Opposing Subcritical Flow Junctions. Journal of Hydraulic Engineering 134(2): 267-273

81. Ghostine R, Mose R, Vazquez J, Ghenaim A, Grégoire C (2010) TwoDimensional Simulation of Subcritical Flow at a Combining Junction: Luxury or Necessity?. Journal of Hydraulic Engineering, p. 799-805.

82. Han-Chung Yang, Cheng-Wu Chen (2012) Potential hazard analysis from the viewpoint of flow measurement in large open-channel junctions. Natural Hazards 61(2): 803-813.

83. Behnam Balouchi, Mohammad Reza Nikoo, Jan Adamowski (2015) Development of expert systems for the prediction of scour depth under live-bed conditions at river confluences: Application of different types ofANNsand theM5Pmodeltree. Applied softcomputing 34: 51-59. 


\section{Civil Engineering Research Journal}

84. Shi-he L, Bing C (2011) Hybrid simulation of the hydraulic characteristics at river and lake confluence. Journal of Hydrodynamics 23(1): 105-113

85. Baranya S, Olsen NRB, Józsa J (2013) Flow analysis of a river confluence with field measurements and RANS model with nested grid approach. River Research Applications 31(1): 28-41.
86. Kothyari UC (1996) Methods for Estimation Sediment Yield from Catchments. Proceedings of International Seminar on Civil Engineering Practice in Twenty First Century, Roorkee, India, p. 1071-1086.

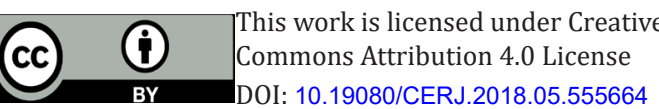

\section{Your next submission with Juniper Publishers will reach you the below assets}

- Quality Editorial service

- Swift Peer Review

- Reprints availability

- E-prints Service

- Manuscript Podcast for convenient understanding

- Global attainment for your research

- Manuscript accessibility in different formats

( Pdf, E-pub, Full Text, Audio)

- Unceasing customer service

Track the below URL for one-step submission https://juniperpublishers.com/online-submission.php 